\title{
Induction of reproductive failure in the planktonic copepod Calanus pacificus by diatoms
}

\author{
Shin-ichi Uye* \\ Faculty of Applied Biological Science, Hiroshima University, 4-4 Kagamiyama 1-Chome, Higashi-Hiroshima 739, Japan
}

\begin{abstract}
A.BSTRACT: The inhibitory effect of diatoms upon egg viability was investigated by feeding the planktonic copepod Calanus pacificus (collected in coastal waters off Oregon, USA) 3 diatom species (Chaetoceros difficilis, Ditylum brightwelli, isolated from Oregon coastal waters, and Thalassiosira

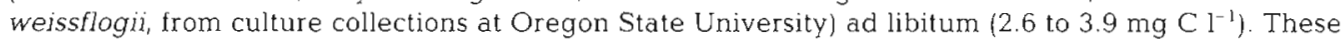
diatoms induced the production of abnormal eggs which failed to hatch or hatched into deformed nauplii. In contrast, a dinoflagellate diet (Prorocentrum minimum, from the culture collections) resulted in the production of normal eggs, $96.6 \%$ of which hatched into healthy nauplii. Diatom inhibitory effect disappeared quickly $(<2$ to 3 d) when females were transferred from diatom suspensions to dinoflagellate suspension. The inhibitory effect was also apparent when newly spawned eggs were exposed to dense diatom cell extracts, indicating that blocking of the embryonic development is chemically mediated. The production of unidentified anti-mitotic chemical compounds by diatoms may be ubiquitous
\end{abstract}

KEY WORDS: Calanus pacificus Diatoms · Embryonic development - Inhibition

\section{INTRODUCTION}

Numerous studies have been conducted to measure the egg production rates of copepods both in the laboratory and in the field. Despite the necessity of examining the viability or hatching success of spawned eggs in determining the population birth rate, this has been often overlooked, or it has been simply assumed that the eggs are viable and will develop into healthy nauplii unless they are subject to predation. However, several studies have reported that the hatching success of copepod eggs varies greatly due to infertility caused by the lack of mating or remating (Parrish \& Wilson 1978, Uye 1981), exposure to deoxygenation (Uye \& Fleminger 1976, Ambler 1985, Roman et al. 1993, Lutz et al. 1994) and the effects of diet (Ambler 1985, Ianora \& Poulet 1993, Jónasdóttir 1994, Guisande \& Harris 1995) including the effect of toxic substances contained in diatom cells (Poulet et al. 1994, Ianora et al. 1995, in press, Miralto et al. 1995).

Diatoms are major microplanktonic primary producers in the ocean, and are particularly important during

•E-mail: suye@ipc.hiroshima-u.ac.jp spring blooms in temperate and boreal waters (Parsons et al. 1984). They are also the dominant phytoplankton in upwelling zones like that found off the coast of Oregon, USA (Small \& Menzies 1981, Small et al. 1989). Diatoms have been regarded as the 'pasture' of the ocean, since they have been thought to be the primary food for herbivorous or suspension-feeding meso- and macrozooplankton such as copepods. However, this classical view of the diatom-zooplankton relationship needs to be reevaluated, since several diatom species have been found recently to inhibit the embryonic development of copepods (Ianora \& Poulet 1993, Poulet et al. 1994 Ianora et al. 1995, in press, Miralto et al. 1995).

The objective of this study is to find whether some common diatom species isolated from coastal waters off Oregon have some inhibitory effect on the embryonic development of Calanus pacificus, one of the common copepod species in the same area. I also used another laboratory-cultured diatom species, Thalassiosira weissflogii, which has been widely used by many plankton researchers (e.g. Paffenhöfer \& Harris 1979) in feeding, growth and egg production experiments for various species of copepods, and has become a sort of 'standard food'. 


\section{MATERIALS AND METHODS}

Effect of diatoms via feeding. Three diatom species (Chaetoceros difficilis, $\mathrm{CD}$; Ditylum brightwelli, $\mathrm{DB}$; and Thalassiosira weissflogii, TW) and 1 dinoflagellate species (Prorocentrum minimum, PM) were used as food for Calanus pacificus. CD and DB were isolated from surface seawater collected at the sampling station ca $10 \mathrm{~km}$ off Newport, Oregon, on April 10, 1995. The other species were derived from culture collections at Oregon State University. Each algal species was grown non-axenically in batch cultures using $1 / 2$ IMR medium (Eppley et al. 1967) at $15^{\circ} \mathrm{C}$ with a $14 \mathrm{~h} \mathrm{light}$ (intensity: $55 \mathrm{~W} \mathrm{~m}^{-2}$ ) and $10 \mathrm{~h}$ dark photoperiod. The cultures were maintained by inoculating $0.2 \mathrm{l}$ of culture into ca $1.8 \mathrm{l}$ medium at intervals of 4 to $5 \mathrm{~d}$ for diatoms and 10 to $12 \mathrm{~d}$ for PM. Algae in exponential growth phase, i.e. 5 to $6 \mathrm{~d}$ old diatoms and 11 to $14 \mathrm{~d}$ old PM, were harvested, enumerated with a hematocytometer, and diluted with $0.2 \mu \mathrm{m}$ filtered seawater to prepare the following concentrations of the rearing media: $2 \times 10^{4}$ cells $\mathrm{ml}^{-1}$ for $\mathrm{CD}$ (cell volume $2920{\mu \mathrm{m}^{3}}^{3}$ ), TW iceil volume: $2540 \mathrm{\mu m}^{3}$ ) and PM (cell volume: $960 \mathrm{\mu m}^{3}$ ) and $1 \times 10^{3}$ cells $\mathrm{ml}^{-1}$ for DB (cell volume: $195800 \mathrm{\mu m}^{3}$ ). The corresponding carbon concentrations were $3.2,2.9,2.6$ and $3.9 \mathrm{mg} \mathrm{Cl}^{-1}$, respectively, according to the cell volume and carbon content relationships of Strathmann (1967). Fresh food treatments were prepared from exponentially growing cultures every 2 d during the experiment.

Female Calanus pacificus were obtained with a plankton net (mouth diameter: $0.7 \mathrm{~m}_{i}$ mesh opening: $243 \mu \mathrm{m}$ ) towed obliquely from $45 \mathrm{~m}$ depth to the surface at the abovementioned station on May 9, 1995. The zooplankton specimens were transferred to $30 \mathrm{l}$ plastic tanks filled with surface seawater and transported to the laboratory within $2 \mathrm{~h}$ of sampling. Upon arrival, healthy-looking females were sorted from the plankton samples and kept in $202 \mu \mathrm{m}$ sieved ambient seawater. Sorting was completed within $5 \mathrm{~h}$ of capture.

Ten Calanus pacificus were maintained with each phytoplankton species as food in a temperature controlled room $\left(12 \pm 0.5^{\circ} \mathrm{C}\right)$ which provided a $14 \mathrm{~h}$ light (ca $5 \mathrm{~W} \mathrm{~m}^{-2}$ ) and $10 \mathrm{~h}$ dark photoperiodicity. Individual females were kept in Plexiglas cylinders (diameter: $7 \mathrm{~cm}$; height: $15 \mathrm{~cm}$ ) with a $335 \mu \mathrm{m}$ sieve $1 \mathrm{~cm}$ above the bottom, which were immersed in beakers containing ca $400 \mathrm{ml}$ of rearing medium. The sieve separated eggs and fecal pellets from the maternal copepod to minimize the cannibalism of eggs and coprophagy of fecal pellets, although the contents of the beakers were stirred to resuspend food particles at 3 to $9 \mathrm{~h}$ intervals. Female copepods which did not lay eggs on Day 1 were replaced with spare female copepods which had spawned. The numbers of eggs and fecal pellets were monitored daily. The eggs were isolated and incubated in a petri dish containing ca $8 \mathrm{ml}$ of $0.2 \mu \mathrm{m}$ filtered seawater. After ca 48 h, the numbers of unhatched eggs and hatched nauplii were noted. If the nauplii were deformed, they were counted separately.

After maintenance in diatom suspensions for $11 \mathrm{~d}, 5$ females from each diatom treatment were transferred to PM suspension. In a similar fashion, 5 females which had been kept in PM suspension were transferred to TW suspension. The remaining females were fed with the same food throughout the experimental period of $18 \mathrm{~d}$

Effect of diatom cell extract. Algal cultures of ca 3.61 were centrifuged at $7000 \mathrm{rpm}(10000 \times g)$ for $30 \mathrm{~min}$ at $5^{\circ} \mathrm{C}$ (Sorvall, RC2-B), the supernatant was removed and algal pellets were washed with $0.2 \mu \mathrm{m}$ filtered seawater into autoclaved plastic vials to yield dense algal suspensions of 25 to $30 \mathrm{ml}$. These suspensions were sonicated (Artek, Model 150) for $3 \mathrm{~min}$ in crushed ice to disrupt the cell membrane. They were recentrifuged as above, and the supernatant was kept frozen in autoclaved vials at $20^{\circ} \mathrm{C}$. Prior to use, this cell extract was thawed at $0^{\circ} \mathrm{C}$ and diluted to various strengths with $0.2 \mu \mathrm{m}$ filtered seawater.

Eight female Calanus pacificus were sorted from the plankton samples caught at the same location as before on June 28,1995 , and were reared individually in PM suspension for $3 \mathrm{~d}$ to confirm that $>92 \%$ of their eggs were capable of hatching into healthy nauplii. Then all females were kept together in a beaker containing PM suspension and their spawning was monitored every 15 to $20 \mathrm{~min}$. Freshly laid eggs were transferred to a petri dish containing ca $5 \mathrm{ml}$ (depth: ca $3 \mathrm{~mm}$ ) of various strengths of the abovementioned cell extracts until examination ca $40 \mathrm{~h}$ later. The shallow depth of water/cell extract assured adequate oxygenation for hatching.

\section{RESULTS}

Daily monitoring of each food treatment resulted in records of fecal pellet production, egg production, hatching success and an assessment of naupliar health. Individual copepods kept in each algal suspension displayed some variability in egg production, but displayed steady fecal pellet production on each food type (Figs. $1 \& 2$ ). Based on these individual data, the mean daily rates of egestion and egg production and the mean fraction of healthy nauplii hatched from the eggs produced were calculated (Figs. 3 to 6), excluding those few copepods which died during the experiment or were judged as genetically abnormal (for example P-3 in Fig 1 and $\mathrm{C}-2$ and $\mathrm{C}-10$ in Fig. 2). 

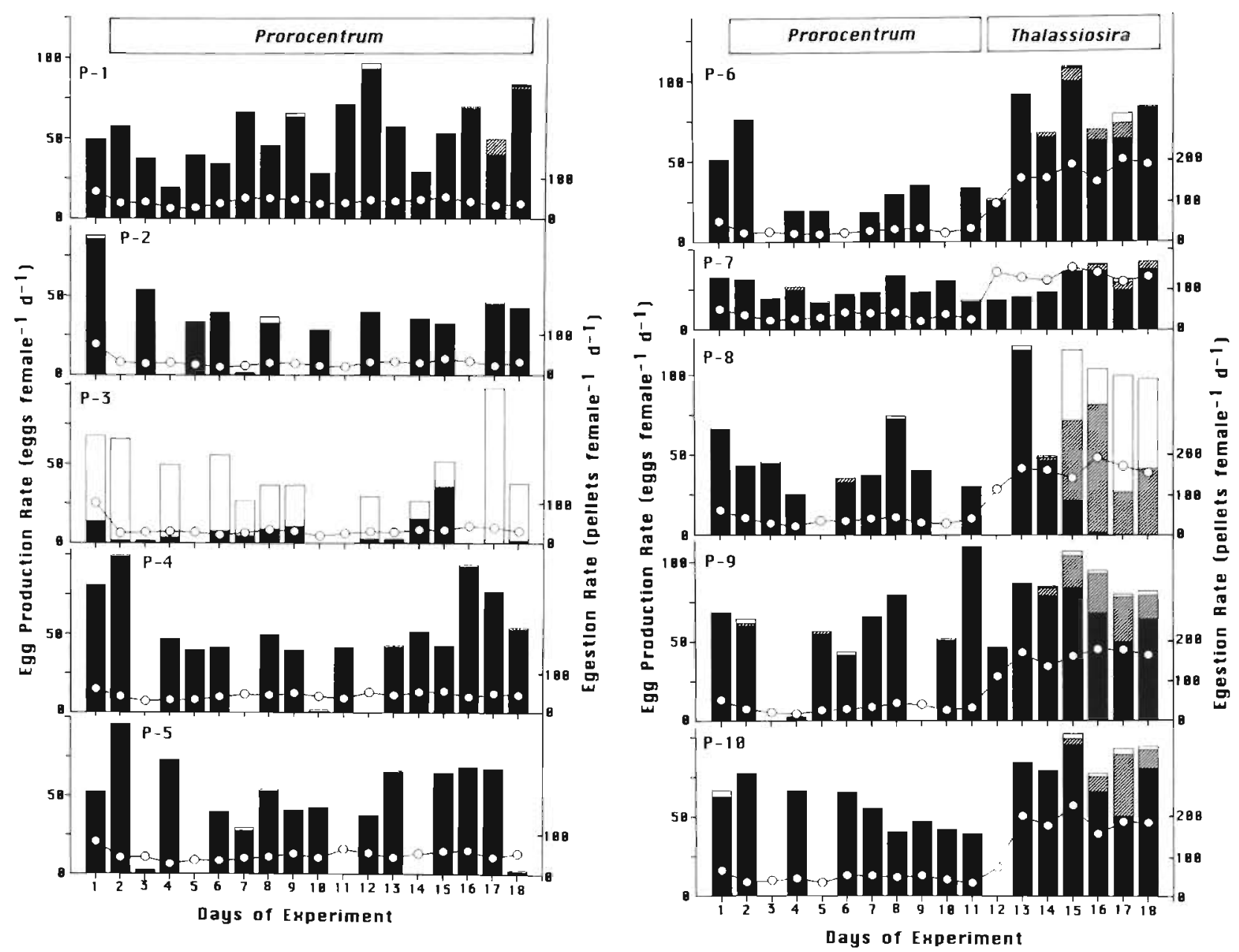

Fig. 1 Calanus pacificus. Daily records of egestion rate $(0)$ and egg production rate (columns) of females fed with Prorocentrum minimum. Eggs were further classified into unhatched eggs (open columns), deformed nauplii (shaded columns) and healthy nauplii (solid columns). Copepods of P-6 to P-10 were transferred on Day 11 to Thalassiosira weissflogii suspension

\section{Egestion rates}

Between Day 2 and Day 18, the daily egestion rates were relatively constant under the respective food conditions (egestion rates noted on Day 1 were influenced by the pre-experiment maintenance diet). The average egestion rate was 38.7 pellets female $\mathrm{e}^{-1} \mathrm{~d}^{-1}$ for females fed with PM (Fig. 3), and was much higher for copepods fed with diatoms $\left(135,126\right.$ and 145 pellets female ${ }^{-1} \mathrm{~d}^{-1}$ for CD, DB and TW, respectively; Figs. 3 to 6).

\section{Egg production rate}

Since Marshall \& Orr (1952) found that the minimum period from feeding of radioactive food to production of radioactive eggs was ca 6 to $8 \mathrm{~h}$ for Calanus finmarchicus, the egg production rate recorded on Day 1 might represent in situ egg production rate. The mean egg production rate on Day 1 was 53.6 eggs female $\mathrm{e}^{-1} \mathrm{~d}^{-1}$. After Day 2 , the fecundity was relatively constant under the same food regime. The average egg production rate was nearly the same for copepods fed with PM, CD and DB (40.1,41.0 and 41.1 eggs female $\mathrm{e}^{-1} \mathrm{~d}^{-1}$, respectively; Figs. 3 to 5). However, it was significantly ( $p<0.05$, Bonferroni multiple comparison procedure) higher (69.6 eggs female $\mathrm{d}^{-1}$ ) for copepods fed with TW (Fig. 6) than for those fed with the other algal species.

\section{Hatching success and anatomical examination of hatched nauplii}

By the time of examination for hatching success, i.e. 48 to $72 \mathrm{~h}$ after eggs were spawned, hatched nauplii had usually developed into naupliar stage (N) II, if the 

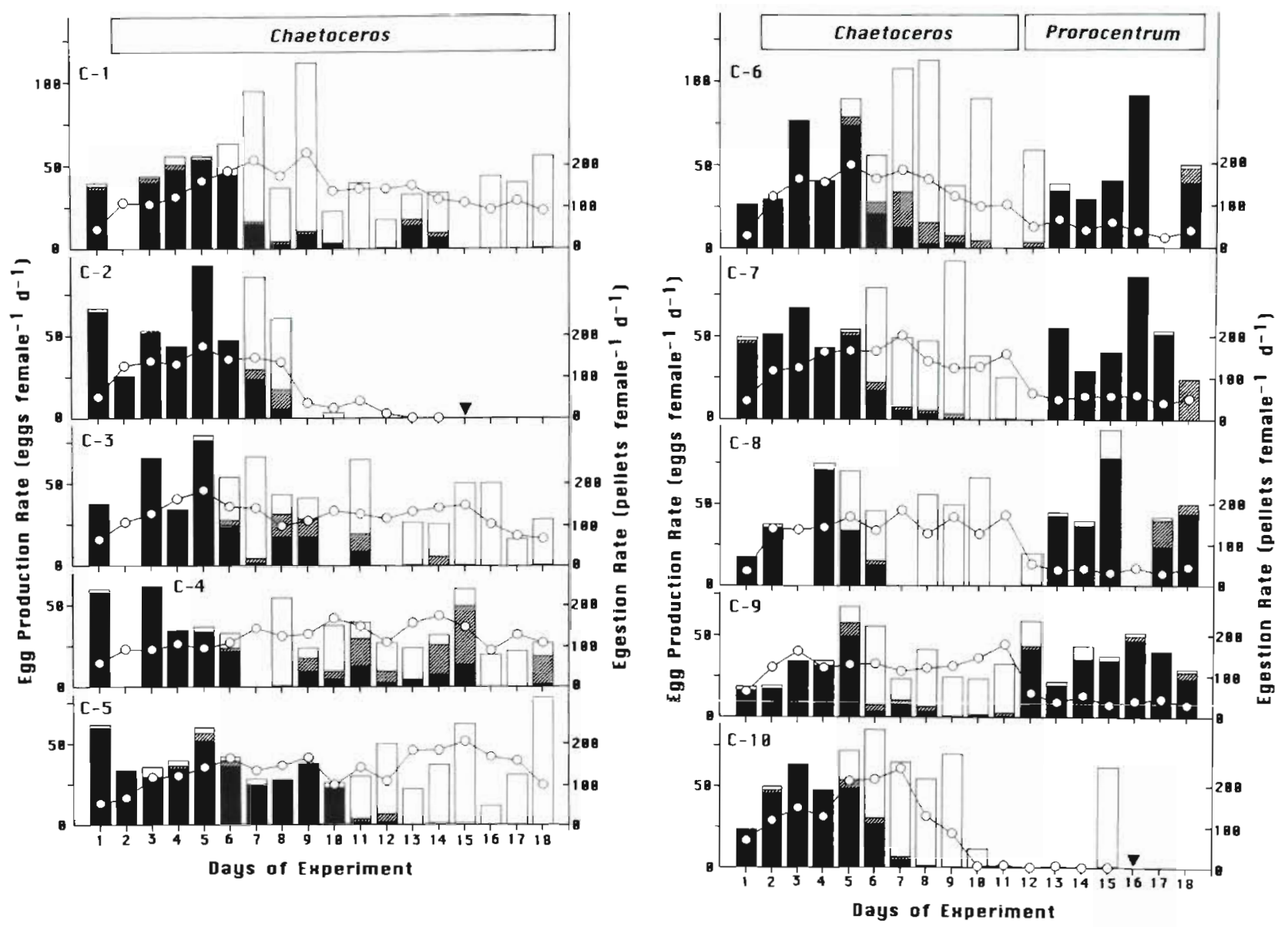

Fig. 2. Calanus pacificus. Daily records of egestion rate (O) and egg production rate (columns) of females fed with Chaetoceros difficilis (liabels as in Fig. 1). Copepods of C-6 to C-10 were transferred on Day 11 to Prorocentrum minimum suspension. ( $\mathbf{\nabla}$ ) Time of death

eggs were normal. In this study, hatching was defined by the complete decapsulation of the nauplius from the inner egg membrane. Embryos which failed to hatch were classified as 'unhatched eggs'. Among hatched nauplii, those with morphological abnormalities were defined as 'deformed nauplii'. The bodies of the deformed nauplii were asymmetrical and crumpled. Their 3 pairs of appendages were also asymmetrical, shortened and abnormal in segmentation. The number and length of setae on the appendages were reduced, and the setae were often stuck together. Considerable numbers of the deformed NI were found dead. If they were still viable, their swimming behavior was hampered so that most of them crawled on the bottom of the dish. In contrast, 'healthy' nauplii had symmetrical bodies with normally segmented appendages bearing fully extended setae (see Marshall \& Orr 1972), and were found swimming actively. Nearly all $(94.6 \%)$ of the Day 1 eggs hatched into healthy nauplii, suggesting that pre-experimental conditions in coastal waters were satisfactory for egg production and development.
Prorocentrum minimum (Figs. 1 \& 3). All females (except P-3) kept in PM suspension spawned eggs which had high success in hatching into healthy nauplii; on average $96.6 \%$ of the eggs spawned hatched into healthy nauplii between Day 2 and Day 18. These results confirmed the previous finding that PM does not cause any deleterious effect upon copepod embryonic development (Ianora \& Poulet 1993, Poulet et al. 1994, 1995, Ianora et al. 1995, in press, Miralto et al. 1995). Five females were transferred from PM suspension to TW suspension on Day 11, and they began producing abnormal eggs which did not hatch or hatched into deformed nauplii ca $4 \mathrm{~d}$ after the transfer. The inhibitory effect of TW is described in detail in a later section.

Chaetoceros difficilis (Figs. 2 \& 4). More than $84.0 \%$ of eggs spawned during the first $5 \mathrm{~d}$ in $\mathrm{CD}$ suspension hatched into healthy nauplii. Then the fraction of either unhatched eggs or deformed nauplii increased sharply. After Day $7,<27.3 \%$ of the eggs hatched into healthy naupli1. No eggs hatched on Days 16 and 17 


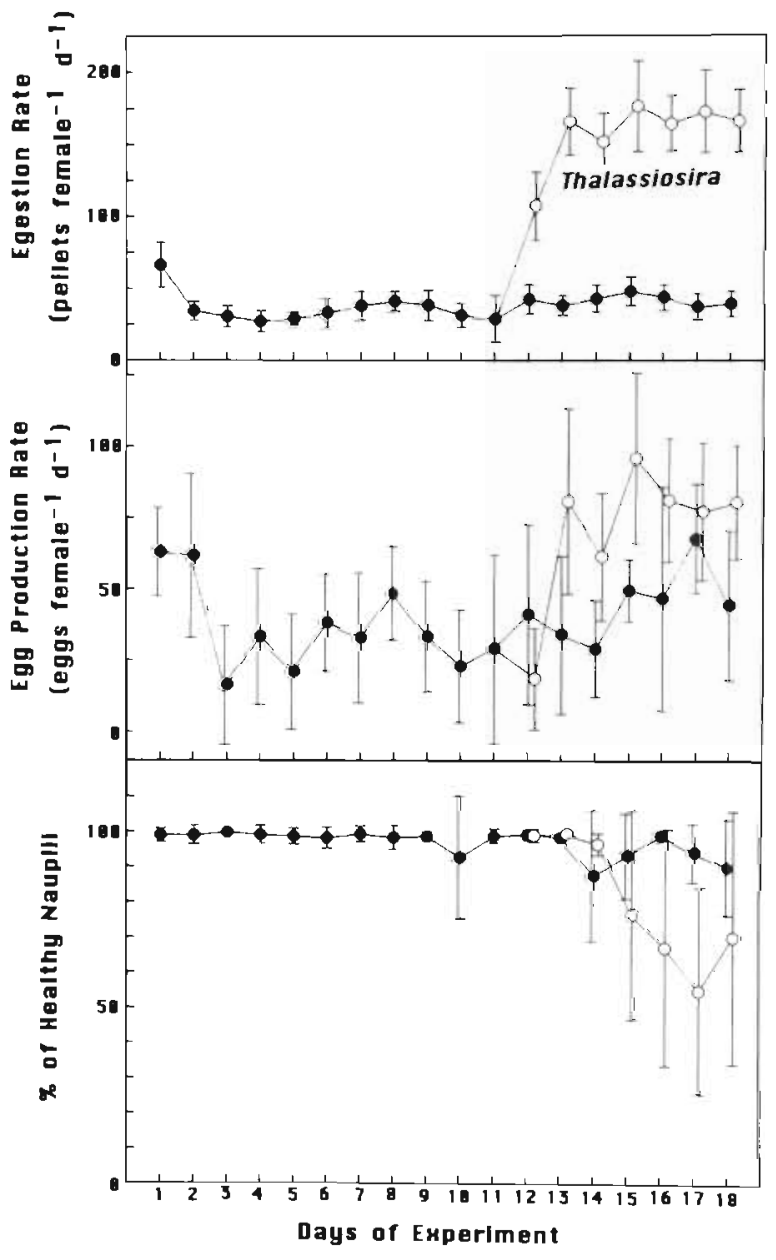

Fig. 3. Calanus pacificus. Variations (means $\pm \mathrm{SD}$ ) in egestion rate, egg production rate and percentage of healthy nauplii of females fed with Prorocentrum minimum (-) and with Thalassiosira weissflogii (O)

On Day 11, half of the females were transferred to PM suspension, and they began producing normal eggs which hatched into healthy nauplii by the second day after the transfer.

Ditylum brightwelli (Fig. 5). After ca 5 d in DB suspension, females began producing abnormal eggs and after Day 9, >90\% of the eggs remained unhatched. In contrast, the females which were transferred to PM suspension began producing normal eggs within $2 \mathrm{~d}$.

Thalassiosira weissflogii (Fig. 6). Eggs spawned in TW suspension until Day 5 hatched into healthy nauplii with $>79 \%$ success, and then hatching success decreased gradually. The inhibition of hatching in TW suspension was less complete compared to $C D$ and $D B$ suspensions. After transfer of females into PM suspension, the recovery of normal egg production was observed within $3 \mathrm{~d}$.

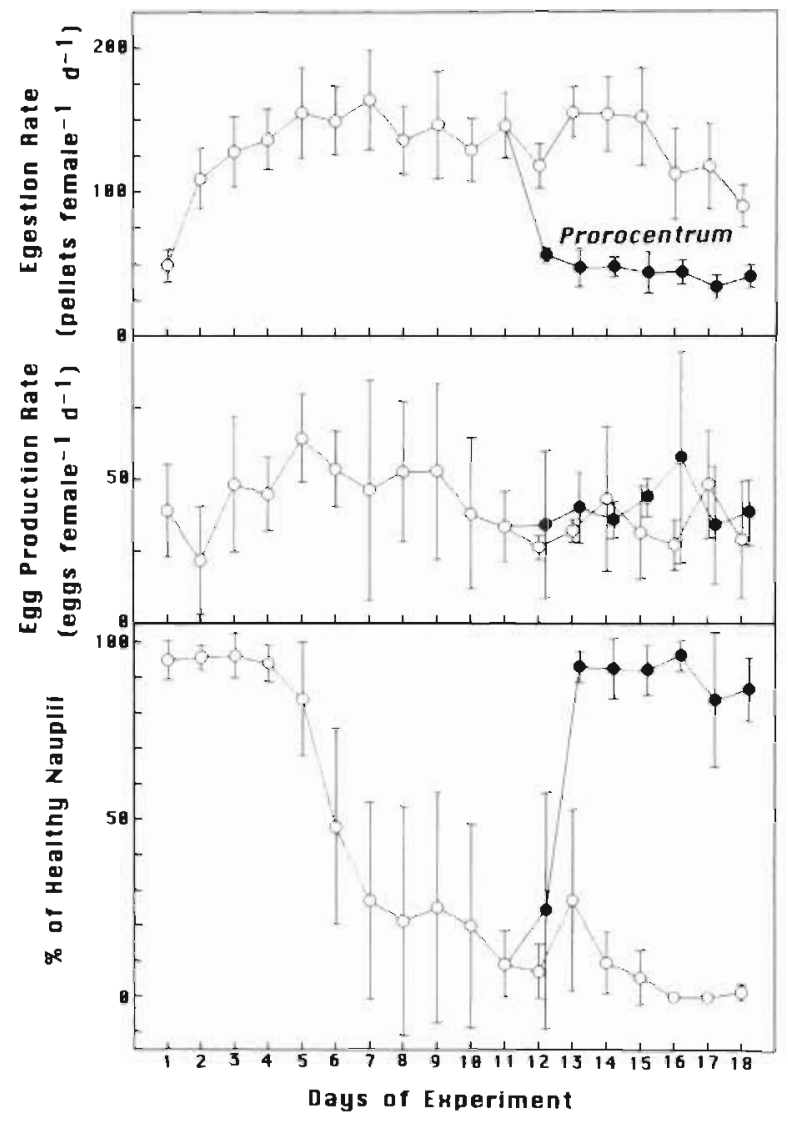

Fig. 4. Calanus pacificus. Variations (means $\pm \mathrm{SD}$ ) in egestion rate, egg production rate and percentage of healthy nauplii of females fed with Chaetoceros difficilis (O) and Prorocentrum. minimum (-

\section{Effect of cell extract}

No harmful effect of PM cell extract was apparent upon viability of eggs (>91\% of eggs hatched into healthy nauplii), while egg viability decreased in dense cell extracts of diatoms (Fig. 7). Less than 16.2\% of eggs hatched into healthy nauplii when the eggs were incubated in cell extracts of CD equivalent to cell concentrations greater than $3.0 \times 10^{5}$ cells $\mathrm{ml}^{-1}$ (i.e. $48 \mathrm{mg} \mathrm{C}^{-1}$ ). In cell extract of DB equivalent to cell concentrations greater than $8.0 \times 10^{4}$ cells $\mathrm{ml}^{-1}$ (i.e. $32 \mathrm{mg}$ $\mathrm{C}^{-1}$ ), no healthy nauplii were obtained. A harmful effect of cell extract of TW was apparent at an equivalent concentration of $3.4 \times 10^{6}$ cells $\mathrm{ml}^{-1}$ (i.e. $490 \mathrm{mg}$ $\left(\mathrm{Cl}^{-1}\right)$.

\section{DISCUSSION}

In this study, care was taken to use algae in exponential growth phase to feed Calanus pacificus, since 


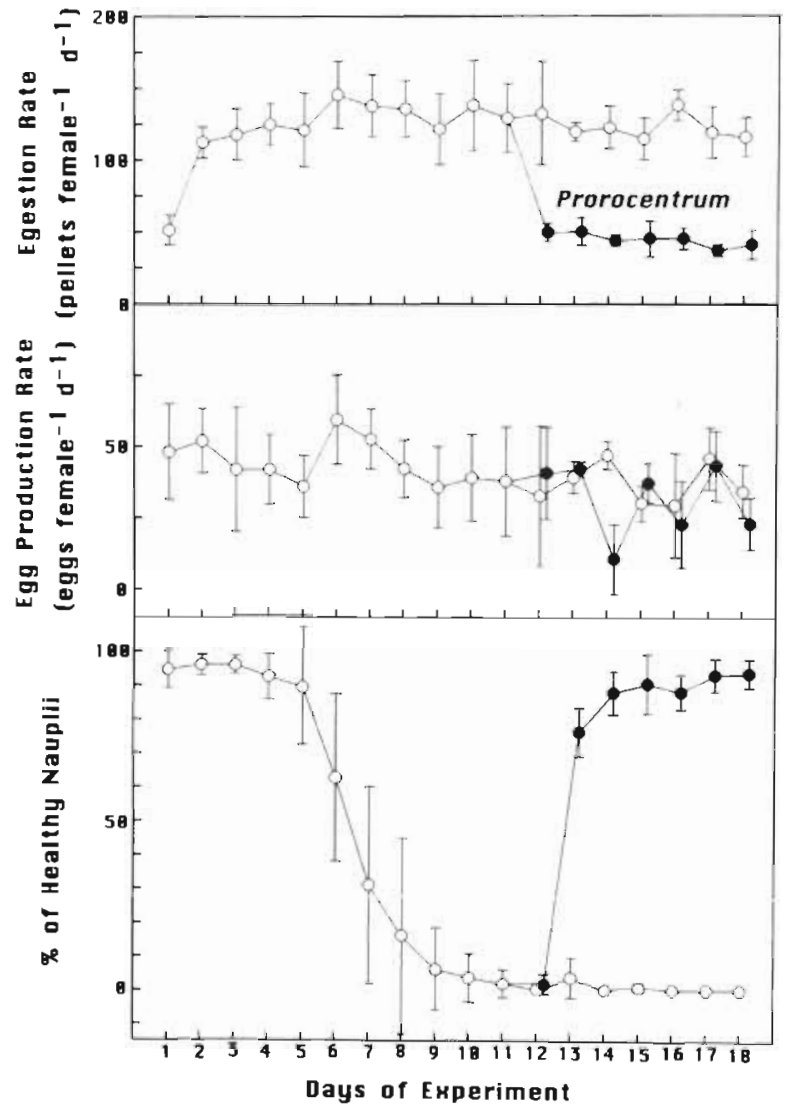

Fig. 5. Calanus pacificus. Variations (means \pm SD) in egestion rate, egg production rate and percentage of healthy nauplii of females fed with Ditylum brightwelli $(0)$ and Prorocentrum minimum (0)

senescent cells can induce lower egg production rate and hatching success in Acartia tonsa (Jónasdóttir 1994). Algal concentrations used in this experiment (2.6 to $3.9 \mathrm{mg} \mathrm{C} \mathrm{l}^{-1}$ ) were ca 1 order of magnitude higher than the critical concentration (200 to $300 \mu \mathrm{g} \mathrm{C}$ $\left.\mathrm{I}^{-1}\right)$, above which the egg production rate of C. pacificus is satiated (Runge 1984). Hence, both egestion rates and egg production rates attained in respective algal suspensions were considered to be close to the potential. Under the same food regime, however, egestion rates were more or less constant, indicating that the copepods' ingestion rates were also constant and their feeding was never restricted, even when they were spawning abnormal eggs. The large difference in the egestion rate between dinoflagellate and diatom diets can be attributed to the presence of indigestible silica frustules in the fecal pellets produced in diatom suspensions.

The egg production rate in PM suspension, which did not cause any deleterious effect on embryonic development, was comparable to those in $\mathrm{CD}$ and $\mathrm{DB}$ suspensions but lower than that in TW suspension.

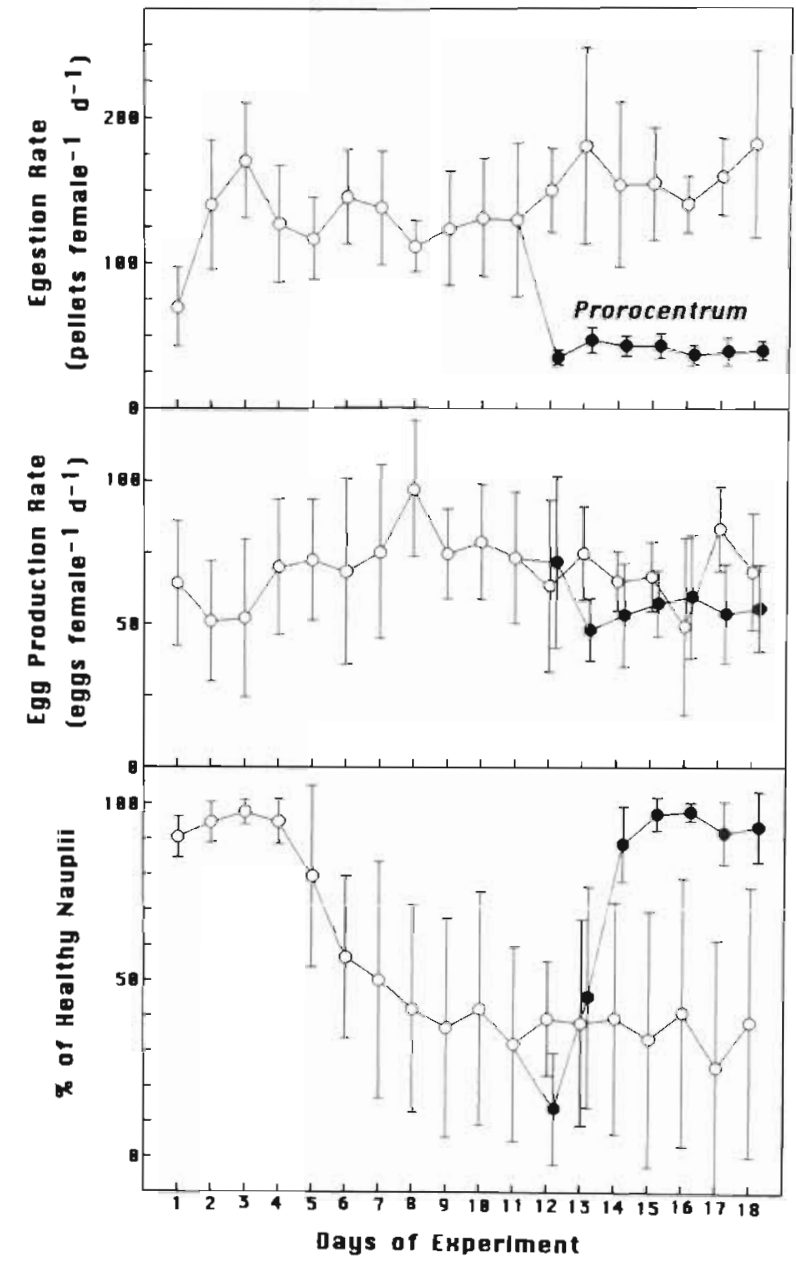

Fig. 6. Calanus pacificus. Variations (means \pm SD) in egestion rate, egg production rate and percentage of healthy nauplii of females fed with Thalassiosira weissflogii $(0)$ and Prorocentrum minimum (

Runge (1984) reported high egg production rates of Calanus pacificus from Puget Sound, USA (ca 50 eggs female $e^{-1} \mathrm{~d}^{-1}$ ) when they were fed with TW ad libitum at $12^{\circ} \mathrm{C}$. This diatom species also supported high egg production rate for Paracalanus parvus (Checkley 1980), but it provided inferior food values, compared to flagellate and dinoflagellate species, for egg production rate of Acartia hudsonica and A. tonsa (Støttrup \& Jensen 1990, Jónasdóttir 1994). The difference in egg production rate depending on algal species might be attributed to chemical composition (Checkley 1980, Cahoon 1981, Ambler 1986, Kiørboe 1989), particularly the contents of protein and specific fatty acids (Støttrup \& Jensen 1990, Jónasdóttir 1994). Meanwhile, despite the difference in the egg production rate due to consumption of different diatom species, all the females fed with these diatoms produced abnormal eggs, indicating that the factors affecting 


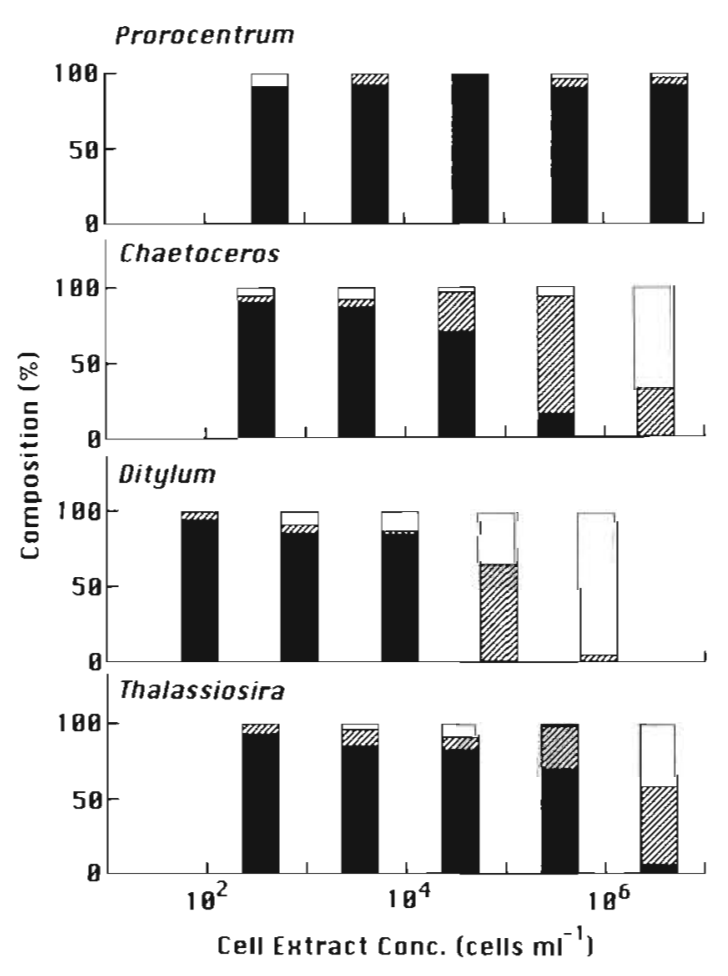

Fig. 7 Calanus pacificus. Effect of various strengths of cell extracts (i.e. equivalent cell concentrations) of Prorocentrum minimum, Chaetoceros difficilis, Ditylum brightwelli and Thalassiosira weissflogii upon egg viability. Results are classified into unhatched eggs (open columns), deformed nauplii

(shaded columns) and healthy nauplii (solid columns)

the egg production rate are different from those affecting egg viability.

Abnormal egg production was induced after ca 5 consecutive days of ingestion of diatom food. The blockage of the embryonic development was most complete in DB suspension, where almost $100 \%$ of eggs remained unhatched after Day 10, and least complete in TW suspension, where a considerable number of eggs hatched into healthy nauplii even in the latter part of the experiment. Such effects were also apparent when newly spawned eggs were incubated in dense diatom cell extracts. A similar arrest of embryonic development has been demonstrated for 4 other copepod species (Acartia clausi, Calanus helgolandicus, Centropages typicus and Temora stylifera) fed with 4 diatom species, Chaetoceros curvisetum, Phaeodactylum tricornutum, Skeletonema costatum and Thalassiosira rotula (Ianora \& Poulet 1993, Poulet et al. 1994, 1995, Ianora et al. 1995, in press). Poulet et al. (1995) also found morphological abnormalities of newly hatched nauplii of $C$. helgolandicus caused by feeding on diatoms or by exposure to dense diatom cell extracts, and they further demonstrated by cytological examination that the anomalous embryonic development was due to erroneous timing in synchronization between nuclear division and formation of the cellular membrane between daughter cells during mitosis.

Causes for such anomalies of copepod embryos due to diatoms have been debated by the above authors, who hypothesized that the failure to develop is attributable to chemical compounds in diatoms which inhibit mitosis during development, rather than to the lack of essential nutrients. Although this hypothesis cannot be proved until the inhibitory chemical compounds can be identified and their functional roles in mitosis can be examined, the results of my experiment (Figs, 3 to 7 ) also support and strengthen this hypothesis. By ingesting only diatoms, Calanus pacificus might accumulate anti-mitotic agents in oocytes during vitellogenesis. The threshold concentration of the agents, above which embryonic development is blocked, was attained after at least $5 \mathrm{~d}$ of ingestion of diatoms ad libitum. If the accumulation of anti-mitotic agents was insufficient to kill the egg, some embryos would develop into deformed nauplii. When food was changed from a diatom to the dinoflagellate, recovery of egg viability took place within 2 to $3 \mathrm{~d}$, possibly coinciding with the time necessary for fresh oocyte development of $C$. pacificus at $12^{\circ} \mathrm{C}$ (Tester \& Turner 1990). During this recovery period, diatom inhibitory substances remaining in the reproductive organs might be removed.

In the field, cell densities during diatom blooms generally range from $10^{2}$ to $10^{4}$ cells $\mathrm{ml}^{-1}$ (Tont 1986 , Chavez et al. 1991), and hence the densities used in this laboratory study $\left(2 \times 10^{4}\right.$ cells $\mathrm{ml}^{-1}$ for CD and TW and $1 \times 10^{3}$ cells $\mathrm{ml}^{-1}$ for DB) are rarely encountered. It is important to investigate whether the diatom inhibitory effect is realistic for copepods in the field. In the Bay of Naples, Italy, Ianora et al. (1992) demonstrated that the hatching success of eggs spawned by Centropages typicus varied from 41 to $94 \%$, although the causes of anomalously low egg viability were not identified. Later, in the same locality, Ianora \& Poulet (1993) found that the periods of low $(<50 \%)$ and high egg viability of Temora stylifera coincided with the periods of high and low diatom biomass, respectively. In the English Channel, the egg viability of Calanus helgolandicus varied widely from $<30$ to ca $100 \%$ depending on the season (Guisande \& Harris 1995, Laabir et al. 1995). Studies on the seasonal variations in composition of phytoplankton species and of diatom frustules in fecal pellets suggested that abnormal egg viability is attributed to the ingestion of diatoms in the field (Laabir et al. 1995). In my experiment, the eggs spawned on Day 1 represented the eggs spawned by wild Calanus pacificus of the coast of Oregon. On average, 53.6 eggs female ${ }^{-1} \mathrm{~d}^{-1}$ were produced, and 
$94.6 \%$ of them hatched into healthy nauplii, showing no diatom inhibitory effect in the field when they were sampled. In coastal waters off Oregon and northern California (USA), phytoplankton, especially diatoms, maintain high standing stock during upwelling seasons (Hood et al 1991, 1992). Therefore, it is likely that the reproductive failure of C. pacificus may occur after intensive diatom blooms. This possibility remains to be investigated.

In addition to 4 diatom species for which some effects deleterious to copepod reproduction have been demonstrated (Ianora \& Poulet 1993, Poulet et al. 1994, 1995, Ianora et al. 1995, in press), this study confirmed that Chaetoceros difficilis, Ditylum brightwelli and Thalassiosira weissflogii also induce reproductive failure in copepods. The former 2 species are very common in coastal waters off Oregon, and the third species has been used widely in laboratory experiments to rear copepods. The results of this study, along with the common occurrence of diatoms in the ocean, suggest that the induction of copepod reproductive failure by diatoms may be a ubiquitous phenomenon. The accumulating evidence about diatom inhibition of egg viability requires a reevaluation of the traditional concept of the prey-predator coupling between diatoms and herbivorous zooplankton.

Acknowledgements. I am grateful to T J. Cowles and C. B. Miller for generous help and valuable comments for this study. I thank W. T Peterson and S. A. Poulet for constructive comments on the manuscript, and L. F. Small for providing information on diatom density in the field. Thanks also to L. M. Fessenden for help with experimental work. This study was conducted while the author was visiting at Oregon State University.

\section{LITERATURE CITED}

Ambler JW (1985) Seasonal factors affecting egg production and viability of eggs of Acartia tonsa Dana from East Laqoon, Galveston, Texas. Estuar Coast Shelf Sci 20: $74: 3.760$

Amble: JW (1986) Effect of food quantity and quality on egg production of Acartia tonsa Dana from East Lagoon, Galveston, Texas. Estuar Coast Shelf Sci 23:183-196

Cahoon LB (1981) Reproductive response of Acartıa tonsa to vanations in food ration and quality. Deep Sea Res $28 \mathrm{~A}$ : $1215-1221$

Chavez FP, Barber RT, Kosro PM, Huyer A, Ramp SR, Stanton TP, de Mendiola BR (1991) Horizontal transport and the distribution of nutrients in the coastal transition zone off northern California: effects on primary production, phytoplankton biomass and species composition. J Geophys Res 96: $14833-14848$

Checkley DM Jr (1980) The egg production of a marine planktonic copepod in relation to its food supply: laboratory studies. Limnol Oceanogr 25:430-446

Eppley RW, Homes RW, Strickland JD (1967) Sinking rates of marine phytoplankton measured with a fluorometer. J Exp Mar Biol Ecol 1:191-208
Guisande C, Harris RP (1995) Effect of total organic content of eggs on hatching success and naupliar survival in the copepod Calanus helgolandicus. Limnol Oceanogr 40: $476-482$

Hood RR, Abbott MR, Huyer A (1991) Phytoplankton and photosynthetic light response in the coastal transition zone off northern California in June $1987 \mathrm{~J}$ Geophys Res 96: $14769-14780$

Hood RR, Neuer S. Cowles TJ (1992) Autotrophic production, biomass and species composition at two stations across an upwelling front. Mar Ecol Prog Ser 83:221-232

Lanora A, Mazzocchi MG, Grottoli R (1992) Seasonal fluctuations in fecundity and hatching success in the planktonic copepod Centropages typicus. J Plankton Res 14: $1483-1494$

Ianora A, Poulet SA (1993) Egg viability in the copepod Temora stylifera. Limnol Oceanogr 38:1615-1626

Ianora A, Poulet SA, Miralto A (1995) A comparative study of the inhibitory effect of diatoms on the reproductive biology of the copepod Temora stylifera. Mar Biol 121. 533-539

Ianora A, Poulet SA, Miralto A, Grottoli R (in press) The diatom Thalassiosira rotula affects reproductive success in the copepod Acartia clausi. Mar Biol

Jónasdóttir SH (1994) Effects of food quality on the reproductive success of Acartia tonsa and Acartia hudsonica: laboratory observations. Mar Biol 121:67-81

Khlor voe T (1989) Phytoplankton growth rate and nitrogen content: implications for feeding and fecundity in a herbivorous copepod. Mar Ecol Prog Ser 55:229-234

Laabir M, Poulet SA, Ianora A, Miralto A, Cueff A (1995) Reproductive response of Calanus helgolandicus. II. In situ inhibition of embryonic development. Mar Ecol Prog Ser 129:97-105

Lutz RV, Marcus NH, Chanton JP (1994) Hatching and viability of copepod eggs at two stages of embryonic development: anoxic/hypoxic effect. Mar Biol 119:119-204

Marshall SM, Orr AP (1952) On the biology of Calanus finmarchicus. VII. Factors affecting egg production. J Mar Biol Ass UK 30:527-547

Marshall SM, Orr AP (1972) The biology of a marine copepod. Springer-Verlag, Berlin

Miralto A, Ianora A, Poulet SA (1995) Food type induces different reproductive response in the copepod Centropages typicus. J Plankton Res 17:1521-1534

Paffenhofer GA, Harris RP (1979) Laboratory culture of marine holozooplankton and its contribution to studies of marine planktonic food webs. Adv Mar Biol 16:211-308

Parrish KK, Wilson DF (1978) Fecundity studies on Acartıa tonsa (Copepoda: Calanoida) in standardized culture. Mar Biol 46:65-81

Parsons TP, Takahashi M, Hargrave B (1984) Biological oceanographic processes. Pergamon Press, Oxford

Poulet SA, lanora A, Miralto A, Meijer L (1994) Do diatoms arrest embryonic development? Mar Ecol Prog Ser 111: $79-86$

Poulet SA, Laabir M, lanora A, Miralto A (1995): Reproductive response of Calanus helgolandicus. I. A.bnormal embryonic and naupliar development. Mar Ecol Prog Ser 129: $85-95$

Roman MR, Gauzens A, Rhinehart WK, White JR (1993) Effects of low oxygen waters on Chesapeake Bay zooplankton. Limnol Oceanogr 38:1603-1614

Runge JA (1984) Egg production of the marine, planktonic copepod, Calanus pacificus Brodsky: laboratory observations. J Exp Mar Biol Ecol 74:53-66

Small LF, Menzies DW (1981) Patterns of primary productıvity 
and biomass in a coastal upwelling region. Deep Sea Res 28:123-149

Small LF, Park H, Nelson DM, Weimer CS (1989) Seasonal dynamics of suspended particulate matter. In: Landry MR, Hickey BM (eds) Coastal oceanography of Washington and Oregon. Elsevier, Amsterdam, p 255-285

Stottrup JB, Jensen J (1990) Influence of algal diet on feeding and egg-production of the calanoid copepod Acartia tonsa Dana. J Exp Mar Biol Ecol 141:87-105

Strathmann R R (1967) Estimating the organic carbon content of phytoplankton from cell volume or plasma volume. Limnol Oceanogr 12:411-418

This article was submitted to the editor
Tester PA, Turner JT (1990) How long does it take copepods to make eggs? J Exp Mar Biol Ecol 141:169-182

Tont SA (1986) W. W. Allen's 20-year phytoplankton collection, Vol 1, Diatoms. IMR Reference No 86-3, Univ California, San Diego

Uye S (1981) Fecundity studies on neritic calanoid copepods Acartia clausi Giesbrecht and A. steueri Smirnov: a simple empirical model of daily egg production. J Exp Mar Biol Ecol 50:255-271

Uye S, Fleminger A (1976) Effects of various environmental factors on egg development of several species of Acartia in Southern California. Mar Biol 38:253-262

Manuscript first received: December 11, 1995

Revised version accepted: January 6, 1996 